\title{
The compound eye of Orgyia antiqua (Lepidoptera: Lymantriidae): Sexual dimorphism and light/dark adaptational changes
}

\author{
Ting Fan (Stanley) LAU ${ }^{1}$ and Victor Benno MEYER-ROCHOW ${ }^{1,2}$ \\ ${ }^{1}$ Faculty of Engineering and Sciences, Jacobs University Bremen, P.O. Box 750561, D-28725 Bremen, Germany \\ ${ }^{2}$ Department of Biology (Zoological Museum), University of Oulu, P.O. Box 3000, SF-90014 Oulu, Finland; \\ e-mail:vmr@cc.oulu.fi and b.meyer-rochow@iu-bremen.de
}

Key words. Lymantriidae, vision, retinal ultrastructure, photic environment, visual behaviour

\begin{abstract}
Structure and photomechanical changes upon light/dark adaptation in the superposition compound eyes of the highly sexually dimorphic Orygia antiqua were studied by light and electron microscopy. The eyes of the fully winged male differ from those of the wingless, sedentary female in several respects: they are significantly larger, display a more regular ommatidial array, have a wider clearzone and possess a much more substantial tracheal tapetum. However, the eyes of the female exhibit more pronounced photomechanical changes upon light/dark adaptation than those of the male. We believe that for females, on account of their limited mobility, it is necessary that their eyes can cope with widely fluctuating brightnesses, but that visual sensitivity and resolving power are less important to them than to the actively flying males. Although the latter may be attracted to the females by pheromones, males in their diurnal searches will have to visually avoid obstacles and predators. Moreover, because of their ability to fly, males can seek shelters or shaded areas and unlike the sedentary females avoid prolonged exposures to potentially hazardous light levels. This could explain why the eyes of the females exhibit more pronounced photomechanical responses to changes in ambient light levels.
\end{abstract}

\section{INTRODUCTION}

Most arthropods live in environments, in which they experience considerable light intensity fluctuations. Often their eyes are capable of adapting to sudden changes in ambient light levels caused by shadows or passing clouds and to the more predictable light intensity differences that accompany dawn and dusk each day. Such adaptational phenomena have received considerable scientific attention (cf., reviews by Autrum, 1981 and Meyer-Rochow, 1999). However, what has largely been ignored in virtually all of the earlier studies was how light/dark adaptational changes vary in individuals of the same species, but different sex and age. For example, Sakura et al. (2003) recently found that only adult males of the cricket Gryllus bimaculatus show a distinct circadian change in rhabdom size under conditions of constant darkness; eyes of nymphs and female crickets do not. This was the first report that demonstrated that day/night morphological changes need not be identical in all developmental stages and the two sexes.

Although the Lepidoptera are one of the four largest orders of insects, with species occurring in a wide range of habitats, studies similar to those on the cricket eye mentioned above to date have not involved a single representative of the Lepidoptera. Studies that covered intraspecific sexual differences in the lepidopteran compound eye were mainly concerned with eye size (Yagi \& Koyama, 1963; Rutowski, 2000), visual field (Ziemba \& Rutowski, 2000; Rutowski \& Warrant, 2002; Merry et al., 2006), external morphology (Baker, 1990; Tung \& Lin, 2000; Ziemba \& Rutowski, 2000) and visual pigment
(Bernard \& Remington, 1991; Stavenga et al., 2001; Arikawa et al., 2005). That kind of research seemed particularly relevant in connection with butterflies like Pieridae (Eisner et al., 1969; Obara, 1970; Rutoswki, 1977) and Lycaenidae (Meyer-Rochow, 1991; Imafuku et al., 2002; Robertson \& Monteriro, 2005), because males and females in these families are not only often strikingly different with regard to their wing UV-reflectivity characteristics, but actually use the UV-signals in sexual recognition. However, with very few exceptions (e.g., Nymphalidae: Viloria et al., 2003) only moths have evolved species with micropterous females, i.e., females with reduced wings or no wings at all, but fully winged males (Hackman, 1966; Heppner, 1991). Species with these kinds of large and obvious sexually dimorphic morphologies seemed interesting candidates for a comparison of male and female eyes, since differences between them had to be the consequence of the different lifestyles, habitats, and behaviours of the two genders of the same species.

The present study focuses on the compound eye of the lymantriid Orgyia antiqua L. O. antiqua females are wingless and display extremely simplified patterns of behaviour: they do not move far from their native cocoons (dispersion is achieved through the very mobile caterpillars: Pinder \& Hayes, 1986). Males, on the other hand, are active during the day and fly around in search of the females in bright sunshine (Günter, 1994). Although chemical communication by sex pheromones is considered to be the primary mode for male and female moths to locate each other (Svensson, 1996), O. antiqua males, like other flying insects, need to see and avoid obstacles 
or predators while searching for their females. One could therefore expect that the male compound eye should exhibit more effective adaptations to cope with ambient dark/light changes than that of the female.

On the other hand, since a winged male, if necessary, can quickly fly to a shelter or an environment, in which fluctuations in brightness are less pronounced, it may not need an adaptational mechanism as efficient as that of the slow and wingless female, for whom it must be an important issue to rapidly and efficiently adjust its photoreceptors to changing levels of brightness. Thus, the aim of this paper has been not only to investigate the morphological and ultrastructural differences between male and female compound eyes in $O$. antiqua, but also the photomechanical responses of these eyes upon exposure to light and dark conditions. As $O$. antiqua is an important forest defoliating species (Grant \& Frech, 1980; Pinder \& Hayes, 1986), this study of the compound eye of $O$. antiqua is expected to be of interest not just to vision researchers or entomologists, but to agricultural scientists and horticulturists as well.

\section{MATERIAL AND METHODS}

\section{Animals and light/dark adaptation experiment}

Eggs of Orgyia antiqua L. were obtained from a private butterfly and moth enthusiast in Joensuu (Finland). Newly hatched larvae were reared to the pupal stage under natural light/dark condition by placing the cage with the caterpillars near the window (approximately 10L : 14D) and feeding the caterpillars with willow leaves (Salix caprea). As the adults emerged from the pupae, they were kept under the same photic environment for $24 \mathrm{~h}$ prior to any light/dark adaptation experiment. To obtain fully daytime light-adapted (LA) individuals, the latter were exposed to daylight (but not direct sunlight) for at least $5 \mathrm{~h}$ prior to decapitation at noon (12:00). Nighttime dark-adapted (DA) individuals were obtained by keeping the animals in total darkness for at least $5 \mathrm{~h}$ before decapitation at midnight (24:00).

\section{Transmission and scanning electron microscopy}

The heads of the specimens were split in half and fixed overnight at $4{ }^{\circ} \mathrm{C}$ in a mixture of $2 \%$ paraformaldehyde and $2.5 \%$ glutaraldehyde, buffered with $0.1 \mathrm{M}$ cacodylate to a $\mathrm{pH}$ of 7.4. Following two washes in $0.1 \mathrm{M}$ cacodylate buffer, the specimens were then postfixed for one hour in $2 \%$ cacodylatebuffered $\mathrm{OsO}_{4}$. After three brief rinses in the same buffer and 2 in distilled water, the specimens were passed through a graded series of ethanol, before an immersion in acetone/Epon mixture for 1 day. Finally the specimens were embedded in Epon resin and hardened for 3 days at a temperature of $60^{\circ} \mathrm{C}$. Semi-thin sections for light microscopy were cut on an ultramicrotome (model-RMC) with a glass knife and stained with $0.5 \%$ toluidine blue on a hotplate. Ultra-thin sections were cut either with a glass or diamond knife and picked up on uncoated 300 mesh copper grids. The sections were then stained with Reynold's lead citrate for $20 \mathrm{~min}$ and $2 \%$ aqueous uranyl acetate for 15 min. Observations took place either under a Zeiss EM 10 transmission electron microscope (TEM), operated at an accelerating voltage of $60 \mathrm{kV}$ or a Philips Tec 12 BioTWIN transmission electron microscope at $80 \mathrm{kV}$.

For observations by scanning electron microscopy (SEM), severed heads of the specimens were dehydrated in a graded series of acetone, air dried, and then sputter-coated with gold (EMI Tech, K550X) to a thickness of approximately $20 \mathrm{~nm}$.
Examinations took place in a Jeol, JSM-5900 scanning electron microscope, operated at $20 \mathrm{kV}$.

\section{Morphometric analysis}

Specimens for scanning electron microscopy were used to determine the width of the eye (distance from dorsal to ventral edge), eye and facet diameters and total number of ommatidia per eye. Light micrographs of longitudinal sections were used for measurements of the corneal radius of curvature, interommatidial angle $(\Delta \varnothing)$, ommatidial length (distance from cornea to basement membrane), thickness of the cornea, cone length, clearzone width, and rhabdom length. Measurements of interommatidial distances, rhabdom areas in cross section and microvillus diameters were gathered from transmission electron micrographs of the mid-rhabdom region, where rhabdoms seemed maximally developed. Diameters of primary and secondary screening pigment granules were determined from transmission electron micrographs of sections through various regions of the eye

In order to quantify and compare photomechanical changes in the compound eye, rhabdom occupation ratio (ROR), defined as rhabdom area/total retinula cell area (cf. Arikawa et al., 1987) and relative clearzone width, defined as width of clearzone/radius of curvature of the eye (cf. Meyer-Rochow \& Gál, 2004) were calculated from parameters measured in transmission electron and light micrographs. The ROR was calculated as follows:

$\mathrm{ROR}=$ rhabdom area/ total retinula cell area

For each eye, at least 15 hexagonally arranged ommatidia were used for measurements on rhabdom areas and interommatidial distances (centre to centre) and the mean value of all inter-ommatidial distances for a given eye was taken as the mean ommatidial diameter. Values for the relative clearzone (cz) were obtained through:

$\mathrm{cz}=$ width of clearzone/ radius of curvature of the eye.

Altogether 3 eyes from males and females were used for measurements in connection with the SEM and 10 measurements were taken from each individual for each parameter. A total of 20 eyes from 20 individuals ( 10 male, 10 female) were examined by light and transmission electron microscopy and 4 to 5 eyes of either sex were used for observations in connection with the light-adapted condition. At least 5 , but most frequently 10 measurements were taken on each of the anatomical features. All the morphological measurements were subject to imageanalysis software Image J (Rasband, W., ImageJ).

\section{Statistical analysis}

The "independent samples" t-test was used to test whether any statistically significant differences were present $(p<0.05)$ between male and female eyes. A "two-way" analysis of variance test (ANOVA) was performed to determine whether there was any statistically significant difference $(p<0.05)$ with regard to the effects of different light conditions between the two sexes. Where significant differences were found in connection with different adaptational states, pair-wise comparisons were used to identify the "degree of difference" between individual groups according to the Tukey Honest Significant Difference (HSD) test $(\mathrm{p}<0.05)$. The "Bonferroni Correction" was made and statistical analyses were performed by using an SPSS statistical package programme.

\section{RESULTS}

\section{General features of male and female eyes}

Both male and female $O$. antiqua possess two compound eyes that occupy lateral positions on either side of 


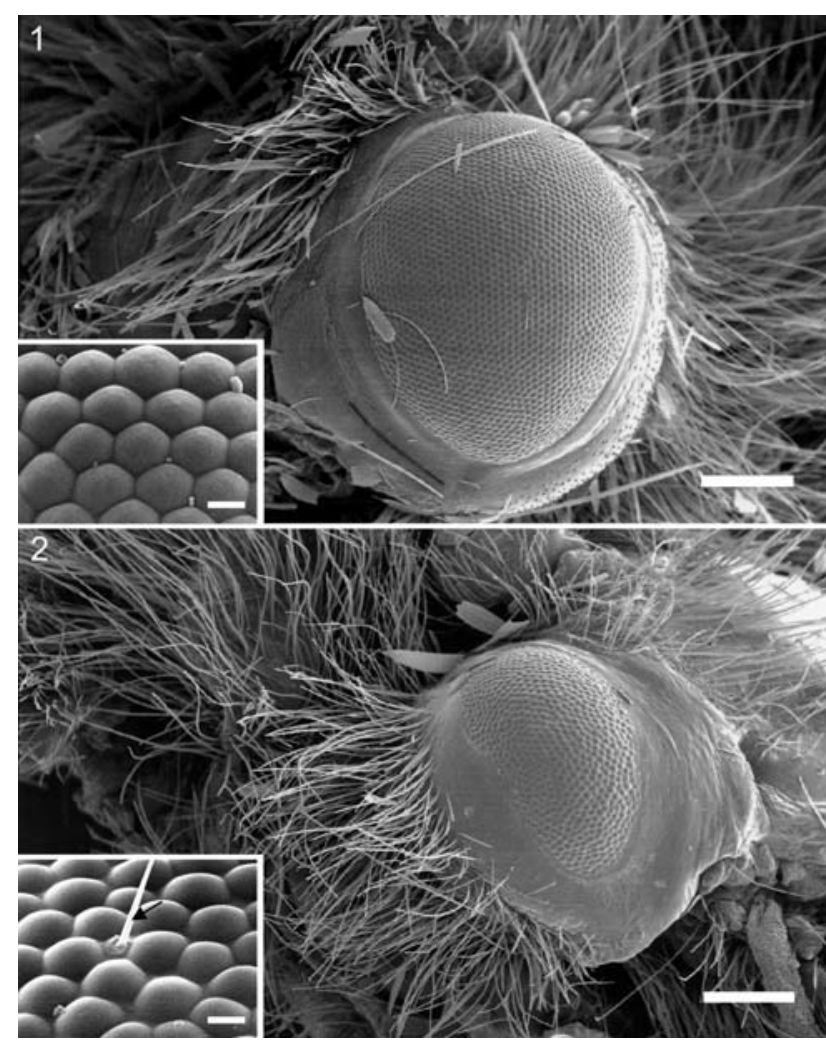

Figs 1-2. Scanning electron micrographs of $O$. antiqua compound eye. 1 - lateral view of the compound eye of the male. 2 - lateral view of the compound eye of the female. The array of facets in the male is more regular than in the female eye. Interfacetal hairs (arrow) are present sporadically on the surface of the eye of both sexes. Scale bar in $1-2=200 \mu \mathrm{m}$, scale bar in Insets $=10 \mu \mathrm{m}$.

the head and are ellipsoid in shape (Figs 1-2). The width of the male eye is $0.77 \mathrm{~mm}$ and it has around 2200 ommatidia; the female eye measures $0.56 \mathrm{~mm}$ in width and contains only approximately 900 ommatidia (Table 1). Observations by scanning electron microscopy revealed that the ommatidia of both sexes are hexagonal in shape (Figs 1-2). The outer surfaces of the facets are covered with tiny corneal protuberances, known as corneal nipples
(Miller, 1979). Interfacetal hairs appear sporadically on the surface of the eyes of both sexes (Fig. 2). Facet diameters in both male and female eyes measure about 18-20 $\mu \mathrm{m}$ (Table 1), but based on qualitative impressions the array of facets is clearly more regular in the male eye.

\section{Anatomical features}

Male and female compound eyes share the general cellular arrangement of the ommatidia (Figs 3-4). However, at semi and ultrastructural level there are considerable differences. Both sexes of $O$. antiqua have a refracting superposition eye. Ommatidial lengths of male and female eyes measure $267 \mu \mathrm{m}$ and $207 \mu \mathrm{m}$, respectively (Table 1). This difference in ommaditial length is statistically highly significant $(\mathrm{p}<0.001)$. Radii of curvature measure $461 \mu \mathrm{m}$ in the male and $327 \mu \mathrm{m}$ in the female eye and were found to be statistically significantly different from each other $(p<0.001$, Table 1$)$.

Each ommatidium consists of a dioptric apparatus, i.e. cornea and cone. Corneal thicknesses in male and female eyes measure $16.7 \mu \mathrm{m}$ and $18.0 \mu \mathrm{m}$, respectively, but these values were not found to be statistically significantly different from each other (Table 1). However, the corneal radius of curvature of the female eye was significantly larger than that of the male $(p<0.05$, Table 1$)$. The crystalline cones in the eyes of both sexes are of the eucone type and cone lengths of 53-58 $\mu \mathrm{m}$ were measured in both sexes. Shapes and sizes of the cones remained the same under different light conditions in both sexes (Table 2). The cones are located directly beneath the corneal lenses and represent more or less solid intracellular structures (hence the designation as "crystalline") that are formed axially by the four contributing cone cells (Figs 5-8). Transverse sections reveal that each group of four cone cells is surrounded by 2 primary pigment and 5-6 secondary pigment cells (Fig. 11). The pigment granules in all of these cells, irrespective of whether primary or secondary pigment cells, measure between $0.4-0.6 \mu \mathrm{m}$ in diameter (Table 1) in both male and female. In both sexes each ommatidium contains 8 retinula cells (7 regular retinula cells and 1 basal cell). The cell bodies of retinula cells $1-7$ ( characterized by their nuclei) are situ-

TABLE 1. Measured values of key anatomical parameters of the eyes of male and female $O$. antiqua.

\begin{tabular}{|c|c|c|c|c|c|c|}
\hline Parameter & Unit & $\begin{array}{c}\text { Male } \\
\text { O. antiqua }\end{array}$ & $n$ & $\begin{array}{c}\text { Female } \\
\text { O. antiqua }\end{array}$ & $n$ & $p$ \\
\hline Number of facets/eye & - & $2224 \pm 44$ & 3 & $900 \pm 20$ & 3 & $* * *$ \\
\hline Width of the eye & $\mathrm{mm}$ & $0.77 \pm 0.018$ & 3 & $0.56 \pm 0.033$ & 3 & $* *$ \\
\hline Diameter of facets & $\mu \mathrm{m}$ & $18.38 \pm 0.24$ & 3 & $17.90 \pm 0.11$ & 3 & NS \\
\hline Ommatidial length & $\mu \mathrm{m}$ & $267.38 \pm 4.98$ & 10 & $207.36 \pm 6.45$ & 10 & $* * *$ \\
\hline Interommatidial angle & Degree & $1.92 \pm 0.11$ & 8 & $3.03 \pm 0.16$ & 6 & $* * *$ \\
\hline Radius of curvature & $\mu \mathrm{m}$ & $461.65 \pm 16.14$ & 10 & $327.26 \pm 10.81$ & 11 & $* * *$ \\
\hline Corneal radius & $\mu \mathrm{m}$ & $17.65 \pm 0.96$ & 10 & $20.94 \pm 0.60$ & 8 & $*$ \\
\hline Corneal thickness & $\mu \mathrm{m}$ & $16.70 \pm 0.24$ & 9 & $17.98 \pm 0.69$ & 7 & NS \\
\hline Diameter of primary pigment cell granule & $\mu \mathrm{m}$ & $0.56 \pm 0.024$ & 4 & $0.55 \pm 0.032$ & 4 & NS \\
\hline Diameter of secondary pigment cell granule & $\mu \mathrm{m}$ & $0.47 \pm 0.018$ & 5 & $0.45 \pm 0.016$ & 5 & NS \\
\hline
\end{tabular}

Data are expressed as mean \pm standard error; $\mathrm{n}$ is the number of eyes measured; $\mathrm{NS}=$ not significant, $*=p<0.05, * *=p<0.01$, $* * *=p<0.001$ in the independent samples t-test. 

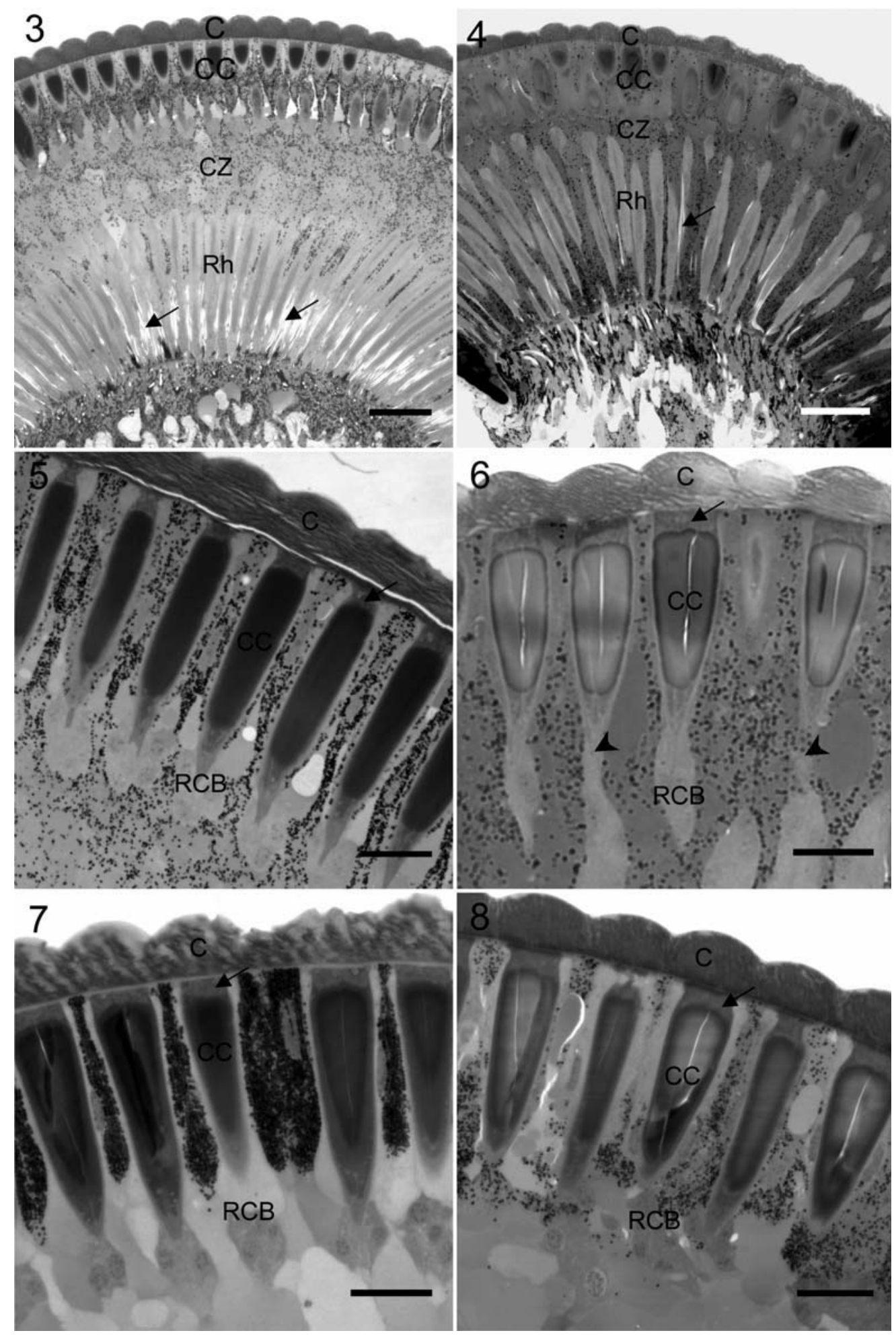

Figs 3-8. Light micrographs of $O$. antiqua compound eye. 3 - longitudinal section through the light-adapted eye of male. A wide clearzone (CZ) separates the cornea $(\mathrm{C})$ and crystalline cone $(\mathrm{CC})$ from the rhabdom layer $(\mathrm{Rh})$. Secondary pigment granules disperse across the clearzone from the cone to the region of the rhabdom. Note that half of the rhabdom length is enveloped by a sheath of tracheae (arrow) 4 - longitudinal section through the light-adapted eye of a female. The clearzone in the female eye is much narrower than that of the male eye. Tracheae appear occasionally around the rhabdom. 5, 7 - the dioptric apparatus of the male eye. $5-$ Light-adapted (LA) state at midday. 7 - dark-adapted (DA) state at midnight. Note different position of screening pigment in the two states. The retinula cell bodies (RCB) remain attached to the tip of the crystalline cone (CC) regardless of the adaptational state. Arrows indicate the nuclei of the cone cells. 6,8 - the dioptric apparatus of female eye. 6 - light-adapted state at midday. 8 - darkadapted state at midnight. Unlike the male eye, the RCBs in the LA-female eye migrate slightly away from the cone tip and leave a very short crystalline tract (arrowhead) in the region which they occupied earlier. Arrows indicate the nuclei of the cone cells. The RCBs remain attached to the tip of the crystalline cone in the dark-adapted eye. Scale bar in 3-4 = 50 $\mu \mathrm{m}$, scale bar in 5-8=20 $\mu \mathrm{m}$ 
TABLE 2. Comparisons of the measured values of the anatomical parameters of the eyes of male and female $O$. antiqua under different light-adaptational states.

\begin{tabular}{|c|c|c|c|c|c|c|c|c|c|c|c|c|}
\hline Parameter & Unit & $\begin{array}{c}\text { Male } \\
\text { O. antiqua }\end{array}$ & $n$ & & $n$ & $\begin{array}{c}\text { Female } \\
\text { O. antiqua }\end{array}$ & $n$ & & $n$ & Sex & $\begin{array}{c}\text { State of } \\
\text { adaptation }\end{array}$ & $\begin{array}{l}\text { Inter- } \\
\text { action }\end{array}$ \\
\hline & & LA & & $\mathrm{DA}$ & & LA & & DA & & $p$ & $p$ & $p$ \\
\hline Cone length & $\mu \mathrm{m}$ & $53.87^{\mathrm{a}} \pm 0.80$ & 5 & $57.77^{\mathrm{a}} \pm 1.56$ & 5 & $56.16^{\mathrm{a}} \pm 1.55$ & 5 & $53.85^{\mathrm{a}} \pm 1.98$ & 5 & NS & NS & NS \\
\hline Clearzone width & $\mu \mathrm{m}$ & $98.97^{\mathrm{a}} \pm 4.76$ & 5 & $104.93^{\mathrm{a}} \pm 3.35$ & 5 & $48.26^{\mathrm{b}} \pm 2.02$ & 5 & $46.55^{\mathrm{b}} \pm 3.38$ & 6 & $* * *$ & NS & NS \\
\hline Relative Clearzone width & - & $0.229^{\mathrm{a}} \pm 0.015$ & 5 & $0.214^{\mathrm{a}} \pm 0.003$ & 5 & $0.149^{\mathrm{b}} \pm 0.013$ & 5 & $0.147^{\mathrm{b}} \pm 0.011$ & 6 & $* * *$ & NS & NS \\
\hline Rhabdom length & $\mu \mathrm{m}$ & $106.40^{\mathrm{a}} \pm 1.57$ & 5 & $103.56^{\mathrm{a}} \pm 3.42$ & 5 & $100.83^{\mathrm{a}} \pm 4.16$ & 5 & $99.59^{\mathrm{a}} \pm 6.35$ & 5 & NS & NS & NS \\
\hline Rhabdom diameter & $\mu \mathrm{m}$ & $4.48^{\mathrm{a}} \pm 0.31$ & 4 & $4.57^{\mathrm{a}} \pm 0.16$ & 4 & $3.99^{\mathrm{a}} \pm 0.18$ & 4 & $4.78^{\mathrm{a}} \pm 0.11$ & 5 & NS & $*$ & NS \\
\hline Rhabdom area & $\mu \mathrm{m}^{2}$ & $15.96^{\mathrm{a}} \pm 2.07$ & 4 & & 4 & $12.60^{\mathrm{a}} \pm 1.12$ & 4 & $17.99^{\mathrm{a}} \pm 0.85$ & 5 & NS & $*$ & NS \\
\hline ROR & $\%$ & $20.40^{\mathrm{a}} \pm 1.91$ & 4 & $22.30^{\mathrm{a}} \pm 1.32$ & 4 & $18.04^{\mathrm{a}} \pm 0.96$ & 4 & $21.89^{\mathrm{a}} \pm 1.87$ & 5 & NS & NS & NS \\
\hline Microvillus diameter & $\mathrm{nm}$ & $68.40^{\mathrm{a}, \mathrm{b}} \pm 2.01$ & 4 & $64.11^{\mathrm{a}} \pm 2.51$ & 5 & $69.80^{\mathrm{a}, \mathrm{b}} \pm 2.65$ & 4 & $75.23^{\mathrm{b}} \pm 2.78$ & 5 & $*$ & NS & NS \\
\hline
\end{tabular}

Data are expressed as mean \pm standard error and $n$ is the number of eyes measured. LA $=$ light-adapted, DA $=$ dark-adapted, ROR $=$ rhabdom occupation ratio, NS $=$ not significant, $*=p<0.05, * *=p<0.01, * * *=p<0.001$ in two way ANOVA test. States marked with the same letter (a and/or b) are not significantly different from one another in the "Bonferroni Correction" $(p<0.05)$.

ated immediately below the tip of the crystalline cone on the distal side of the clearzone. In male $O$. antiqua, the retinula cell bodies remain attached to the cone tips regardless of the adaptational state (Figs 5, 7). However, in the light-adapted eye of the female, the retinula cell bodies migrate slightly away from the cone tip, leaving behind a very short crystalline tract (Fig. 8). The 7 retinula cell bodies then form a slim retinula cell tract, held together by desmosomes (Fig. 12), which in both male and fermale eye run all the way from the tip of the cone to near the basal lamina as thickened membrane structures near the rhabdom/cytoplasm transition (Figs 12-20). The retinula cell tract traverses the clearzone, which seems to be formed by the pigment-free extensions of the secondary pigment cells. The clearzone is between 99-105 $\mu \mathrm{m}$ wide in male and only half as wide (46-49 $\mu \mathrm{m})$ in female eyes. The relative clearzone measures $0.21-0.23$ and 0.15 in males and females, respectively. Both clearzone and relative clearzone differences are statistically highly significant $(\mathrm{p}<0.001)$, but their widths do not change under varying light conditions (Table 2; Fig. 21). Interommatidial angles of male and female eyes measure $1.9^{\circ}$ and $3.0^{\circ}$, respectively, and were found to be statistically significantly different from each other $(\mathrm{p}<$ 0.001, Table 1).

The photoreceptor layer lies on the proximal side of the clearzone. Transverse sections through the rhabdom layer show that the male eye has a much more regular photoreceptor mosaic than that of the female eye (Figs 9-10). Moreover, the shapes of the female rhabdoms are far less regular than those of the male (Figs 9-10, 15-18). The other major difference that is immediately noticeable from light micrographs of transverse sections, is the presence of tracheoles around the rhabdom (Figs 3-4, 9-10). In the male, the ommatidia are surrounded by layers of air-filled tracheoles which run halfway up the rhabdom (Fig. 3). Tapetal sheaths like these are absent from the female eye and only occasionally does one see a few tracheoles around the rhabdom in them (Figs 10, 16, 18). Transmission electron micrographs of transverse sections of the male eye reveal that 6 rhabdomeres merge to form a closed, central rhabdom at the distal end of the rhabdom (Fig. 13). A little more proximal retinula cell 7 contributes its rhabdomere to the rhabdom, so that then altogether 7 retinula cells form the centrally-fused rhabdom, which reaches a maximum diameter of 4.4-4.6 $\mu \mathrm{m}$ in the mid-region of the rhabdom (Fig. 15, Table 2). No significant differences between the diameters of rhabdoms from male and female eyes or different light conditions (below) were observed (Table 2).

Each of the seven photoreceptor cells contributes a triangular, wedge-shaped rhabdomere to the rhabdom, which is star-shaped in cross section (Figs 15 and 17). The microvillar organization of the rhabdomeres remains unchanged throughout the length of the rhabdom until the rhabdomeres diminish in size and become displaced by the basal cell just above the basement membrane (Fig. 19).

In the female eye the closed and centrally-fused rhabdom, like that of its male counterpart, starts distally with a rhabdom of initially 6 rhabdomeres (Fig. 14), boosted a little further proximally by a seventh rhabdomere. The rhabdom then expands to full size at mid-level measuring 3.9-4.8 $\mu \mathrm{m}$ in diameter (Fig. 16). However, in contrast to the male eye, rhabdom diameters in the female eye increase significantly ( $p<0.05$ : two-way ANOVA) in the dark-adapted state (Table 2). Compared with the highly regular male rhabdom, the rhabdomeric contributions of each retinula cell are relatively unbalanced in the female eye, giving its rhabdoms rather irregular shapes and sizes (Figs 16 and 18). Furthermore, unlike the situation in the male eye, where the entire rhabdom column is formed by the rhabdomeres of only 7 retinula cells, 8 retinula cell are involved in the formation of the proximal rhabdom third in the female eye (Fig. 18). This arrangement remains unchanged until the rhabdomeres diminish in size, turn into axons (Fig 4F) and eventually penetrate the basement membrane as distinct bundles of 8 fibres per ommatidium in both male and female eyes (Figs 19-20).

There are 3 major directions of microvillar orientations in both male and female, offset by more or less 120 degree against each other (Figs 13-18). The diameters of 

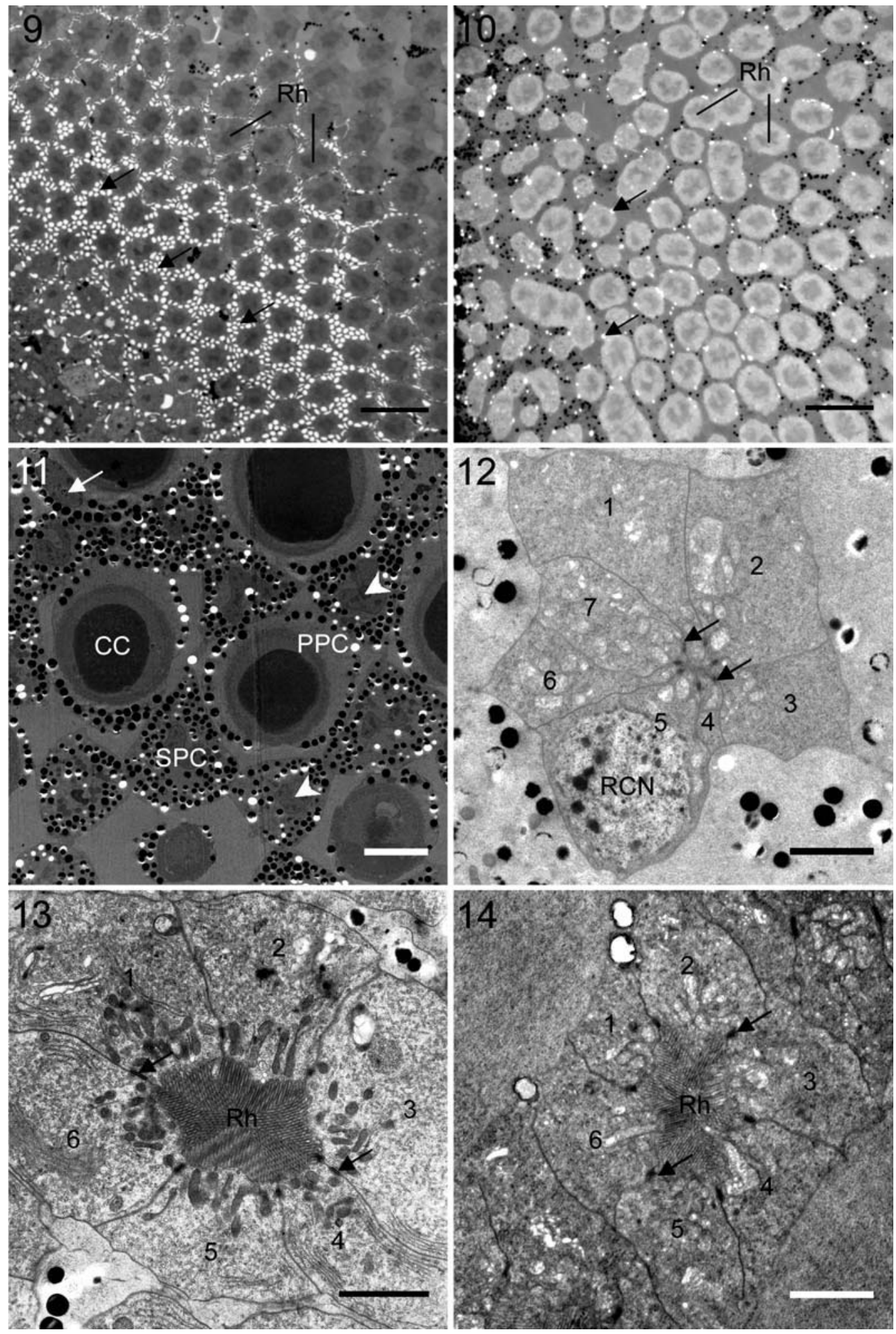

Figs 9-14. Light and Transmission electron micrographs of O.antiqua compound eye. 9 - transverse section through the rhabdom $(\mathrm{Rh})$ layer of the male eye. The rhabdom is surrounded by numerous air-filled tracheoles (arrow). 10 - transverse section through the rhabdom region of the female eye. Compared with the highly regular rhabdomeric pattern in the male eye, the female retinal layer is more irregular and the rhabdom shows a more irregular shape. 11 - the crystalline cone (CC) of the female eye. The cone is surrounded by 2 primary pigment cells (PPC) containing a single row of primary pigment granules. The crystalline cone and primary pigment cell are surrounded by 5 secondary pigment cells (SPC). The nuclei (arrowhead) of the SPC can also be seen at this level. The arrow at the left hand corner indicates the nuclei of the primary pigment cell. 12 - transverse section across a retinula cell tract in the male eye formed by 7 retinula cells, showing retinula cell nuclei (RCN) and desmosomes (arrow) between the retinula cells. 13 - transverse section through the distal region of the rhabdom of the male eye. 14 - transverse section through the distal region of the rhabdom of the female eye. The rhabdom is formed by the contribution of 6 retinula cells at this level in both sexes. Desmosomes are indicated by arrows. Scale bar in $9-10=20 \mu \mathrm{m}$, scale bar in $11=5 \mu \mathrm{m}$, scale bar in $13-14=2 \mu \mathrm{m}$ 

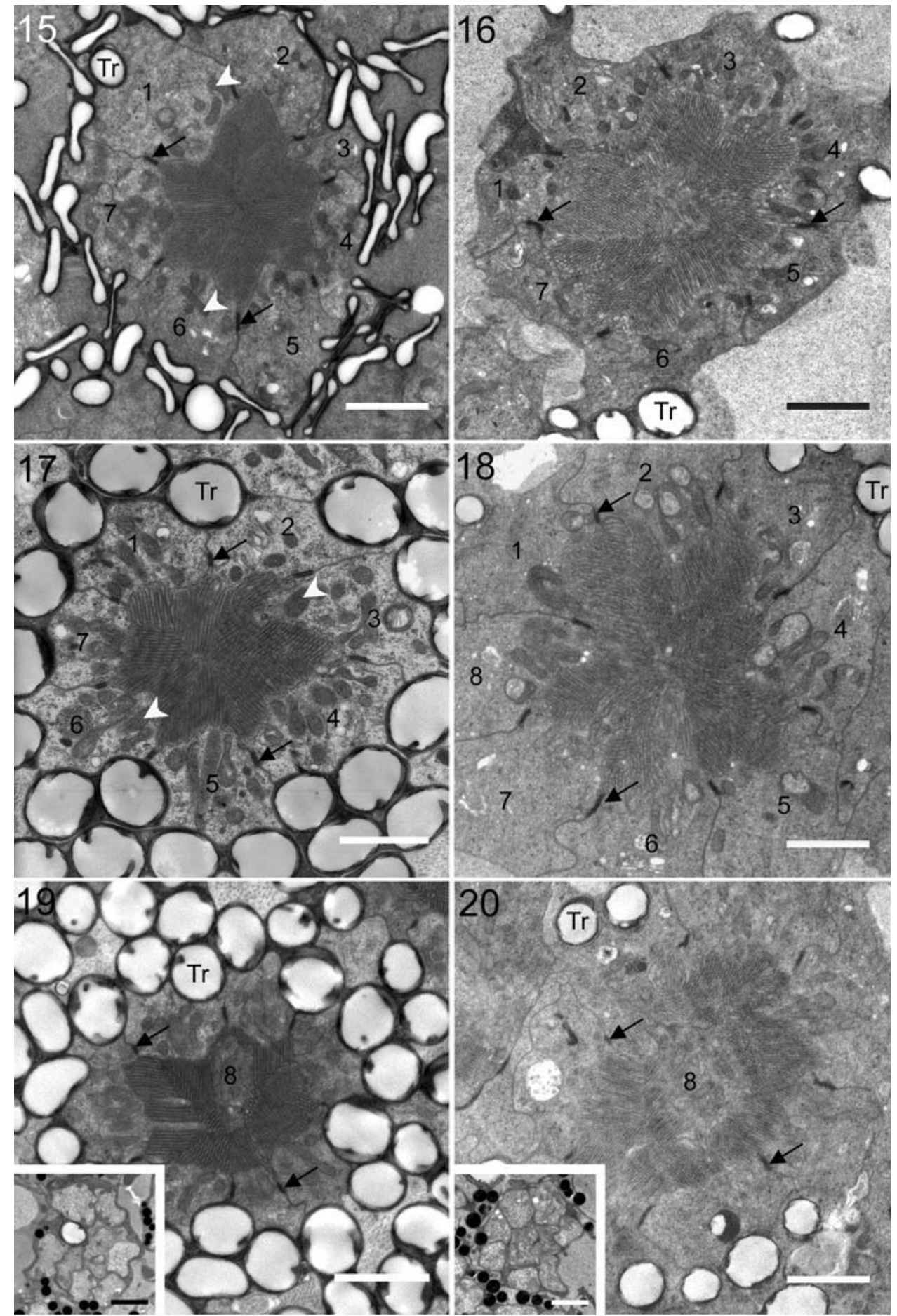

Figs 15-20. Comparisons of eye ultrastructure in male and female $O$. antiqua. 15 - transverse section through the medial region of the rhabdom of the male in the light adapted state, showing the rhabdom is formed by 7 triangular rhabdomeres. 16 - transverse section through the medial region of the rhabdom of female, showing the rhabdom is formed by 7 triangular rhabdomeres. Note the contribution of the rhabdomere by each retinula cell is relatively unbalanced compared with the male rhabdom. 17 - transverse section through the medial proximal region of the rhabdom of the male in the dark-adapted state, showing the rhabdom is formed by 7 triangular rhabdomeres. The rhabdomere of R1 is very small at this level. Note the number of mitochondria (arrowhead) in the retinula cell of night-adapted eye is higher than that of the light-adapted eye (15). 18 - transverse section through the medial proximal region of the rhabdom of the female, showing the rhabdom is formed by 8 rhabdomeres from 8 retinula cells. 19 - transverse section through the basal region of the male rhabdom. The $8^{\text {th }}$ retinula cell (basal cell) is situated in the centre of the rhabdom. $20-$ transverse section through basal region of female rhabdom, showing similar profile to that of the male. Insets: Transverse section of axon bundle with 8 fibres of male (19) and female eye (20). Arrows indicate the presence of desmosomes, running all the way from the distalmost region to the proximal tip of the rhabdom column in both males and females. In male eyes a tracheal tapetum (Tr) surrounds each ommatidial group of retinula cells, shielding it from neighbouring ommatidia. Scale bar in $15-20=2 \mu \mathrm{m}$, scale in insets $=1 \mu \mathrm{m}$. 
the microvilli measure $64-68 \mathrm{~nm}$ in the male and $69-75$ $\mathrm{nm}$ in the female eye. The difference in microvillus diameters was statistically significant for the dark-adapted state $(\mathrm{p}<0.05$, Table 2$)$, but for the light-adapted no such difference between male and female eyes was present (Table 2). Intracellular organelles like mitochondria, multivesicular bodies, endoplasmic reticula, etc were common in the retinula cytoplasm of dark as well as lightadapted male and female eyes and, at least with regard to the mitochondria, showed differences in abundance in relation to different ambient light levels (Figs 15, 17).

\section{Major light/dark adaptational changes}

Both male and female eyes exhibit very pronounced pigment translocations upon light/dark adaptation. In the light-adapted eyes of both sexes, spherical pigment granules of approx. $0.4-0.6 \mu \mathrm{m}$ in diameter, belonging to the secondary pigment cells, disperse into and across the clearzone from the cone region to the rhabdom layer (Figs 3-4). In the male eye, the pigment sheath extends halfway across the rhabdom layer to where the tapetal envelope begins (Fig. 3). In the female eye, screening pigment granules migrate even further and also surround most to the proximal half of the rhabdom layer (Fig 4). During dark adaptation, the screening pigment granules aggregate distally around the cones (Figs 7-8), leaving the clearzone free of pigment in the eyes of both sexes.

In contrast to the granules of the secondary pigment cells, those of the primary pigment cells in both male and female eyes show almost no migrational change under different ambient light conditions. There were also no significant changes with regard to clearzone width (Table 2, Fig. 21) in LA and DA states of both sexes. The widths of the rhabdom layer (103-107 $\mu \mathrm{m}$ in the male) and (99-101 $\mu \mathrm{m}$ in the female) remain the same in all adaptational states (Table 2), but in the central region of the compound eyes of both males and females, the ROR in the DA state $(21-23 \%)$ is greater than that seen in LA-specimens (18-20\%) (Table 2, Fig. 22). Despite the significantly increased rhabdom diameters, especially in the darkadapted female eye, the ROR was not statistically significantly different between the two extreme states of adaptation. Since screening pigment granules vacate the zone around the retinula cells during dark-adaptation and no tracheolar sheath is developed in the female eye, the retinula cytoplasm can expand and occupy a larger space during dark-adaptation. Hence, an increased rhabdom and a more voluminous retinula cell cancel each other out and lead to an apparently unchanged ROR, even though rhabdom diameters are actually larger in the dark. Apart from the changes affecting clearzone and the rhabdom size, mitochondrial numbers in the retinula cells of DA specimens of both sexes were significantly elevated over the numbers recorded from the LA samples (Figs 15, 17).

\section{DISCUSSION}

Male $O$. antiqua have bigger eyes than females and although this result does agree with observations by Yagi \& Koyama (1963), who investigated about 80 species from 25 lepidopteran families and found that male eyes were always bigger than those of females, it is not selfunderstood that this has to be so: there are insects like Hypothenemus hampei (the coffee berry borer beetle), for instance, in which the reverse holds true. However, unlike butterflies, which posses apposition eyes and in which males increase eye size by incorporating larger facets into their compound eyes (Ziemba \& Rutowski, 2000; Rutowski \& Warrant, 2002), males of the moth $O$. antiqua increase their eyes by adding more facets of identical diameter and shape to the compound eye. Acute zones, i.e. specialized regions with higher acuity than the rest of the eye to spot and chase females, are known from some Odonata and Diptera (Hornstein et al., 2000; Land \& Eckert, 1985; Collect \& Land, 1975), but seem to be generally absent from superposition eyes with the exception perhaps of the day-active Macroglossum stellatarum hawkmoth, whose eye departs radically from the classical principles of Exnerian superposition optics (Warrant et al., 1999).

As $O$. antiqua has a typical refracting superposition eye, the image is formed by focusing light from a large patch of corneal facet lenses across the clearzone to form an erect superposition image onto the retinal layer. In such an eye there is no "acute zone" and its strength lies in improved absolute sensitivity to light rather than acuity (Land, 1989). More facets, however, and a reduction of interommatidial angle combined with a wider clearzone not only can increase sensitivity, but can also affect resolution positively. Since considerable differences in male and female $O$. antiqua eyes with regard to clearzone widths, facet numbers, and interommatidial angles exist, we should expect different functional strengths in the two eyes.

\section{General organization and optical properties of male and female eyes}

Despite the rather different numbers of facets, superficially male and female eyes seem remarkably similar and gross-anatomically there are indeed few differences, e.g. both have similar corneal shapes and thicknesses, share cone and rhabdom lengths and possess 8 retinula cells per ommatidium (Tables 1-2). However, the female has a poorly developed clearzone (half the width of that of the male) and consequently a significantly shorter ommatidium. Other differences are the smaller radius of corneal curvature in the male eye and the larger interommatidial angles in the female. A more convex corneal lens is often considered to be an adaptation to a dim light environment as in some nocturnal mosquitoes with apposition eyes and an almost hemispherical lens (Land et al., 1999) or as in midwater euphausiids with clearzone eyes and strongly curved corneal facets (Meyer-Rochow \& Walsh, 1978).

When the eye is in the dark-adapted state, the secondary pigment granules migrate distally and aggregate around the cones. Since the ommatidia are then not optically isolated, the clearzone allows light that enters the eye through many facets to be focused on more or less one photoreceptor. Meyer-Rochow \& Gál (2004) found that in order to form an image that is optimally bright, the animal needs a large angular field of view $(\gamma)$, but this can 
only be achieved with a wider clearzone. As the relative clearzone width of the male (0.214) is significantly larger than that of the female $(0.147)$, the light gathering ability of the male is undoubtedly much superior to that of the female.

Yet, sensitivity is only one of the requirements for an eye to be a useful detector of environmental features. The animal still needs to have sufficient spatial (and temporal) resolving power to distinguish image detail and to react to objects that enter its visual field while in flight. In view of the fact that image formation in the superposition eye is achieved by concentrating light rays that enter the eye through many facets, creating a wide aperture (Kunze, 1979; Land, 1981), the latter can cause spherical aberration and lead to a spatial spread, known as the "blur circle", around the focal spot. The result is a worsening of spatial resolution vis-à-vis an increasing aperture (Land, 1981; Warrant \& McIntyre, 1990, 1991). To deal with this dilemma and to retain the incident light rays within the target rhabdom, Nature has found several solutions for the superposition eye (Warrant \& McIntyre, 1991). One of the most effective methods is to partially or completely surround the rhabdom with a tapetal reflector which internally reflects oblique rays, thus preventing cross-over of rays into neighbouring rhabdoms.

\section{The retinula and its photoreceptors}

The rhabdoms of male $O$. antiqua are much more rigorously sheathed by air-filled tracheoles than those of the female, so that one is reminded of the eyes of other diurnally active moths such as skipper butterflies (Horridge et al., 1972) and Phalaenoides tristifica (Horridge et al., 1977), which are known to have high resolution superposition eyes. Since there is no optical isolation between neighbouring rhabdoms in the female eye, light rays that strike a rhabdom at a large incident angle (Warrant \& McIntyre, 1990; McIntyre \& Caveney, 1998) can pass through the target rhabdom and eventually enter and pass through a succession of neighbouring rhabdoms. The non-target rhabdoms may produce an error signal and inevitably blur the image, causing a loss in resolving power. Although we do not have optical data on the position of the superposition image formed by the dioptric apparatus in the eye of $O$. antiqua, the superposition images from other moths like Ephestia kühniella (Cleary et al., 1977; Kunze, 1979) and Phalaenoides tristifica (Narvarro \& Franceschini, 1998) are located deep in the eyes at distances of $125 \mu \mathrm{m}$ and $137 \mu \mathrm{m}$ respectively. The widths of the clearzone of Ephestia kühniella and Phalaeoides tristifica are about $100 \mu \mathrm{m}$ (Fischer \& Horstmann, 1971) and $137 \mu \mathrm{m}$, respectively (Narvarro \& Franceschini, 1998) and thus agree with values from the eye of male $O$. antiqua (99-106 $\mu \mathrm{m}$, Table 2). On the basis of these values we estimate that in male $O$. antiqua, the superposition image would fall on approximately $28-40 \%$ of the rhabdom.

In the case of the female eye, the rhabdom can be as near as $46 \mu \mathrm{m}$ from the proximal cone tip. Any superposition image would, therefore, fall onto the rhabdom's $79-91 \%$ region, i.e. $12 \%$ of the rhabdom, which is much less than in the male. Even though the superposition image formed in the female eye is still contained within the region of the rhabdom, with an image so deep in the rhabdom layer, one would expect the light beams to have spread across a substantial number of rhabdoms especially when the rhabdoms are not isolated by surrounding sheaths of tracheoles.

Apart from the optics of the $O$. antiqua eye, what we have not yet discussed is the irregular photoreceptor mosaic of the female eye. French et al. (1977) showed that an irregular retinal array reduces the signal amplitude, degrades the signal by the addition of background noise to the visual system. This would work against spatial as well as temporal resolution. In contrast to the regular photoreceptor pattern of the male, the irregular facet array of the female eye thus further suggests that the latter is not designed for high flicker fusion frequency or sharp acuity. In fact, the male eye possesses a significantly smaller interommatidial angle $\left(1.9^{\circ}\right)$ than the female $\left(3.0^{\circ}\right)$ and since narrow interommatidial angles correlate with improved resolving power, it only underscores our conclusion that the eye of the male possesses a much superior spatial and temporal resolving power than that of the female.

\section{Ultrastructural differences between male and female eyes}

Both male and female possess 7 distally located retinula cells and 1 proximal retinula cell (basal cell) per ommatidium. A basal cell with its own rhabdomere occurs in many lepidopterans with clearzone eyes such as skippers (Horridge et al., 1972; Shimohigashi \& Tominaga, 1986), armyworm moths (Meinecke, 1981), sphingids (Eguchi, 1982) and saturniids (Anton-Erxleben \& Langer, 1988) as well as some other insects with clearzone eyes like scarab beetles (Gokan \& Meyer-Rochow, 2000). As with many of these species, the basal retinula cell in the ommatidium of male $O$. antiqua has a centrally-projecting rhabdomeric process that wedges between the other retinula cells and contributes to the rhabdom for a short distance close to the proximal end of the rhabdom column (Horridge \& Giddings, 1971; Horridge et al., 1972; Meinecke, 1981; Shimohigashi \& Tominaga, 1986). However, in female $O$. antiqua, the basal cell's rhabdomere takes part in the composition of the main rhabdom column and not just its most proximal end (corresponding to the rhabdom region that in the male is formed exclusively by $\mathrm{R} 1$ to $\mathrm{R} 7$ retinula cells).

This arrangement differs not only from male $O$. antiqua, but also quite distinctly from the other lepidopteran species and scarab beetles mentioned above. The functional significance of the basal cell has yet to be fully understood. A microspectrophotometric study by Schlecht et al. (1978) revealed that the proximal, basal cell R9 in the moth Deilephila elpenor was a violet receptor, whereas in the butterflies, Papilio (Arikawa, 2003) and Pieris rapae (Qiu \& Arikawa, 2003), the R9 receptor is either a green or a red receptor. Horridge et al. (1972) suggested that due to the small volume of the rhabdomere, the basal cell can be expected only to work 
at much higher light intensities than the other retinula cells. Therefore, he mused, it might be useful for an insect, which flies from shade to sunlight with little apparent change in acuity.

In the case of the female eye, the significance of the 8 th rhabdomere remains obscure. One possible explanation could be that it increases the otherwise poor sensitivity of the eye. As the rhabdomeres of R1 to R7 start to diminish in size at the mid-proximal level, the contribution of the basal cell's rhabdomere can to some degree compensate for the decrease in rhabdom volume and assist to maintain sensitivity. One other noteworthy feature of the rhabdoms of male and female eyes concerns the microvillus orientation in them. Even though there are altogether 3 major directions recognizable in both male and female, the microvilli are somewhat curved and not strictly oriented in 3 directions. Compared with the dorsal rim area of the eye, which is used by many insects for the detection of polarized skylight (Labhart \& Meyer, 1999), the microvilli in this area are always straight and oriented in two orthogonal directions. It is safe to conclude that the eyes of both sexes may not be specialized to be sensitive to polarized light. Moreover, especially the microvillus diameters of the female in the dark-adapted state are significantly wider than those of the male eye.

\section{Light/ dark adaptational changes}

At first thought it is surprising to find that the female eye should exhibit more pronounced photomechanical reactions, following light/dark adaptation, than the male eye. However, both male and female $O$. antiqua respond to different light conditions mainly by pigment granule translocations. The eyes show little change in ROR at different light levels. Drastic increases in rhabdom diameters from day to night have been reported in many species of arthropods like horseshoe crab (Chamberlain \& Barlow, 1984), brachyuran crabs (Grapsus grapsus: Nässel \& Waterman, 1979; Hemigrapus sanguineus: Arikawa et al., 1987), and Ocypode spp.: Rosenberg \& Langer, 2001), plague locust (Locusta migratoria: Williams, 1982) and numerous other insects (cf. review by MeyerRochow, 1999). Some of these species are active in full sunlight as well as in the dark of night. Their eyes need to function over a wide range of light intensities.

The rather weak photomechanical response and the low ROR in the $O$. antiqua eye (20-22\%), compared with the $50-80 \%$ recorded in a nocturnal moth (Eguchi, 1978), suggests that $O$. antiqua may be predominantly active in relatively bright light or has no need to adjust its eyes to varying intensities. In fact, for some strictly diurnallyactive moths like skippers (Horridge et al., 1972) and Phalaenoides tristifica (Horridge et al., 1977), it could be shown that their pigment granules do not migrate at all and anatomical changes upon light/dark adaptation do not occur. Apart from increasing the sensitivity of the eye in the dark, the main purpose of the light/dark adaptational changes is to prevent photic damage by limiting the amount of light reaching the photoreceptor in times when light levels are very intense. Unlike the male that can fly into shady areas if necessary, the female is almost immo- bile and therefore in greater need of adjustments to protect her vision under photic conditions that contain potentially harmful radiation or dangerously high light intensities.

\section{Functional implication of the male and female eye}

We have demonstrated that male $O$. antiqua possesses eyes with superior acuity and sensitivity compared with those of the female. Day-active, flying insects generally appear to have a compound eye with high resolution like dragonflies (Laughlin \& McGinness, 1978), houseflies (Laughlin \& Weckström, 1993), butterflies (Rutowski \& Warrant, 2002), honey- and bumblebees (Laughlin \& Horridge, 1971; Meyer-Rochow, 1981) and some diurnally-active moths (Horridge et al., 1977), especially when there is a need for the insect to evade predators, visually procure food, or search for a mate by sight. As $O$. antiqua is a capital breeder, i.e. does not feed as an adult and has a short life span (Tammaru \& Haukioja, 1996; Tammaru et al., 2002; Esperk \& Tammaru, 2006), one could expect that this species would rely solely on the resources derived from the larval stage for searching a mate (in the male) and laying eggs (in the female). The female is simply in less need of having a well functioning eye and as it moves no further than a short distance (i.e., centimeters) away from its cocoon, its compound eye may only be used to lead it from an exposed spot to a safer area, i.e. from a sunny to a shadowy place to lay eggs.

Interestingly, the highly sexually dimorphic firefly, Rhagophthalmus ohbai (Lau \& Meyer-Rochow, 2006) shows a similar pattern to that of $O$. antiqua in that its female does not feed as an adult and is rather sedentary. However, the nocturnally-active wingless female firefly possesses an apposition eye with no more than 40 facets, while the fully-winged male has a functional superposition eye with more than 2000 facets. Obviously, functional requirements exert a powerful evolutionary pressure on the designs of the compound eye, its optics and retinal ultrastructure, but unless more comparative analyses are conducted we will find it difficult to understand how phylogenetic background and ecophysiological needs combine to produce the differences seen in male and female insect photoreceptors.

ACKNOWLEDGMENTS. We wish to thank H. Schikora (University of Bremen) for the rearing of Orgyia antiqua to the pupal stage from eggs received through J. Matero in Joensuu (Finland). We would like to express our gratitude to the Electron Microscopy Unit, run by W. Heyser of the University of Bremen, for access to their facilities. Finally, we would like to thank D.W.T Au for allowing us to use the Electron Microscope and the staff of the Microscopic Imaging Unit, City University of Hong Kong.

\section{REFERENCES}

Anton-Erxleben F. \& Langer H. 1988: Functional morphology of the ommatidia in the compound eye of the moth, Antheraea polyphemus (Insecta: Saturniidae). Cell Tissue Res. 252: 385-396.

ARIKAWA K. 2003: Spectral organization of the eye of a butterfly, Papilio. J. Comp. Physiol. (A) 189: 791-800. 
Arikawa K., Kawamata K., Suzuki T. \& Eguchi E. 1987: Daily changes of structure, function and rhodopsin content in the compound eye of the crab, Hemigrapsus sanguineus. J. Comp. Physiol. (A) 161: 161-174.

Arikawa K., WaKakuwa M., Qiu X., Kurasawa M. \& Stavenga D.G. 2005: Sexual dimorphism of short-wavelength photoreceptors in the small white butterfly, Pieris rapae crucivora. $J$. Neurosci. 25: 5935-5942.

Autrum H. 1981: Light and dark adaptation in invertebrate. In Autrum H. (ed.): Handbook of Sensory Physiology. Vol. VII/6C. Springer, Berlin, pp. 1-91.

BAKER G.T. 1990: Morphology of eyes and sensory receptors of larval and adult stages of Thyidopteryx ephemeraeformis Haworth (Lepidoptera: Psychidae). Mississippi Agric. Forest Exp. Sta. 170: 1- 11.

Bernard G.D. \& Remington C.L. 1991: Color vision in Lycaena butterflies: Spectral tuning of receptor arrays in relation to behavioural ecology. Proc. Natl. Acad. Sci. 88: 2783-2787.

Chamberlain S.C. \& Barlow R.B. 1984: Transient membrane shedding in Limulus photoreceptors: Mechanisms under natural lighting. J. Neurol. Sci. 11: 2792-2810.

Cleary P., Deichsel G. \& Kunze P. 1977: The superposition image in the eye of Ephestia kühniella. J. Comp. Physiol. 119: $73-84$.

Collett T.S. \& Land M.F. 1975: Visual control of flight behaviour in the hoverfly, Syritta pipiens L. J. Comp. Physiol. 99: $1-66$.

EGUCHI E. 1978: Comparative fine structure of Lepidopteran compound eyes, especially Skippers (Hesperioidea). Zool. Mag. 87: 32-43.

EGUCHI E. 1982: Retinula fine structure in compound eyes of diurnal and nocturnal sphingid moths. Cell Tissue Res. 223: $29-42$.

Eisner T., Silberglied R.E., Aneshansley D., Carrel J.E. \& Howland H.C. 1969: Ultraviolet video-viewing: The television camera as an insect eye. Science 166: 1172-1174.

EsPerk T. \& TAMmaru T. 2006: Determination of female-biased sexual size dimorphism in moths with a variable instar number: The role of additional instars. Eur. J. Entomol. 103: 575-586.

Fischer A. \& Horstmann G. 1971: Der feinbau des augen der mehlmotte, Ephestia kuehniella zeller (Lepidoptera: Pyralididae). Z. Zellforsch. 116: 275-304.

French A.S., Snyder A.W. \& Stavenga D.G. 1977: Image degradation by an irregular retinal mosaic. Biol. Cybernetics 27: 299-233.

GoKan N. \& Meyer-Rochow V.B. 2000: Morphological comparisons of compound eyes in Scarabaeoidae (Coleoptera) related to the beetle's daily activity maxima and phylogenetic positions. J. Agric. Sci. 45(1): 15-61.

GRANT G.G. \& FRECH D. 1980: Disruption of pheromone communication of the rusty tussock moth, Orgyia antiqua (Lepidoptera: Lymantriidae), with (Z)-6-heneicosen-11-one. Can. Entomol. 112: 221-222.

GüNTER E. 1994: Die Schmetterlinge Baden-Württembergs, Bd. 4 Nachtfalter II. Eugen Ulmer, Stuttgart, 535 pp.

HACKMAN W. 1966: On wing reduction and loss of wings in Lepidoptera. Notul. Entomol. 46: 1-16.

HEPPNER J.B. 1991: Brachyptery and aptery in Lepidoptera. Trop. Lepid. 2: 11-40.

Hornstein E.P., O'Carroll D.C., Anderson J.C. \& Laughlin S.B. 2000: Sexual dimorphism matches photoreceptor performance to behavioural requirements. Proc. R. Soc. Lond. (B) 267: 2111-2117.
Horridge G.A. \& Giddings C. 1971: The retina of Ephestia (Lepidoptera). Proc. R. Soc. Lond. (B) 179: 87-95.

Horridge G.A., Giddings C. \& Stange G. 1972: The superposition eye of skipper butterflies. Proc. R. Soc. Lond. (B) 182: 457-495.

Horridge G.A., McLean M., Stange G. \& Lillywhite P.G. 1977: A diurnal moth superposition eye with high resolution Phalaenoides tristifica (Agaristidae). Proc. R. Soc. Lond. (B) 196: $233-250$.

Imafuku M., Hirose Y. \& Takeuchi T. 2002: Wing colors of Chrysozephyrus butterflies (Lepidoptera: Lycaenidae): Ultraviolet reflection by males. Zool. Sci. 19: 175-183.

KunZe P. 1979: Apposition and Superposition eyes. In Autrum H. (ed.): Handbook of Sensory Physiology. Vol. VII/6A. Springer, Berlin, Heidelberg, NewYork, pp. 441-502.

Labhart T. \& Meyer P.E. 1999: Detectors for polarized skylight in insects: A survey of ommatidial specializations in the dorsal rim area of the compound eye. Microsc. Res. Tech. 47: 368-379.

LAND M.F. 1981: Optics and visions in invertebrates. In Autrum H. (ed.): Handbook of Sensory Physiology. Vol. VII/6B. Springer, Berlin, Heidelberg, NewYork, pp. 471-592.

LAND M.F. 1989: Variations in the structure and design of compound eyes. In Stavenga D.G. \& Hardie R.C. (eds): Facets of Vision. Springer, Berlin, Heidelberg, pp. 90-111.

LAND M.F. \& ECKERT H. 1985: Maps of the acute zones of fly eyes. J. Comp. Physiol. (A) 156: 525-538.

Land M.F., Gibson G., Horwood J. \& Zeil J. 1999: Fundamental differences in the optical structure of the eyes of nocturnal and diurnal mosquitoes. J. Comp. Physiol. (A) 185: 91-103.

Lau S.T.F. \& MeYer-Rochow V.B. 2006: Sexual dimorphism in the compound eye of Rhagophthalmus ohbai (Coleoptera: Rhagophthalmidae). J. Asia-Pac. Entomol. 9: 1-12.

LAUGHLIN S.B. \& HorRidge G.A. 1971: Angular sensitivity of retinula cells of dark-adapted worker bee. Z. Vergl. Physiol. 74: $329-335$.

Laughlin S.B. \& McGinNess S. 1978: The structures of dorsal and ventral regions of a Dragonfly retina. Cell Tissue Res. 188: 427-447.

LaUGHLin S.B. \& WeCKSTRÖM M. 1993: Fast and slow photoreceptors - a comparative study of the functional diversity of coding and conductances in the Diptera. J. Comp. Physiol. (A) 172: 593-609.

McIntyre P. \& CAVeney S. 1998: Superposition optics and the time of flight in onitine dung bettles. J. Comp. Physiol. (A) 183: 45-60.

MeINECKE C.C. 1981: The fine structure of the compound eye of the african armyworm moth, Spodoptera exempta Walk. (Lepidoptera: Noctuidae). Cell Tissue Res. 216: 333-347.

Merry J.W., Morehouse N.I., Yturralde K. \& Rutowski R.L. 2006: The eye of a patrolling butterfly: Visual field and eye structure in the orange sulphur, Colias eurytheme (Lepidoptera: Pieridae). J. Insect Physiol. 52: 240-248.

MeYer-Rochow V.B. 1981: Electrophysiology and histology of the eye of the bumblebee Bombus hortorum (L.) (Hymenoptera: Apidae). J. R. Soc. New Zealand 11: 123-153.

MEYER-Rochow V.B. 1991: Differences in ultraviolet wing patterns in the New Zealand lycaenid butterflies, Lycaena salustius, L. rauparaha, and L. feredayi as a likely isolating mechanism. J. R. Soc. New. Zealand. 21: 169-177.

MeYer-Rochow V.B. 1999: Compound eye: circadian rhythmicity, illumination, and obscurity. In Eguchi E. \& Tominaga Y. (eds): Atlas of Arthropod Sensory Receptors: Dynamic Morphology in Relation to function. Springer, Tokyo, pp. 97-124. 
Meyer-Rochow V.B. \& GÁL J. 2004: Dimensional limits for arthropod eyes with superposition optics. Vision Res. 44: 2213-2223.

Meyer-Rochow V.B. \& Walsh S. 1978: The eyes of mesopelagic crustaceans: III. Thysanopoda tricupidata (Euphausiacea). Cell Tissue Res. 195: 59-79.

Miller W.H. 1979: Ocular optical filtering. In Autrum H. (ed.): Handbook of Sensory Physiology. Vol. VII/6A. Springer, Berlin, Heidelberg, NewYork, pp. 69-143.

NäSSEL D.R. \& Waterman T.H. 1979: Massive diurnally modulated photoreceptor membrane turnover in crab light and dark adaptation. J. Comp. Physiol. 131: 205-216.

Narvarro R. \& Franceschini N. 1998: On image quality of microlens arrays in diurnal superposition eyes. Pure. Appl. Opt. 7: L69-L78.

Obara Y. 1970: Studies on the mating behaviors of the white cabbage butterfly, Pieris rapae crucivora Boisduval III. Nearultra-violet reflection as the signal of intraspecific communication. Z. Vergl. Physiol. 69: 99-116.

PinDER P.S. \& HaYes A.J. 1986: An outbreak of vapourer moth, Orgyia antiqua L. (Lepidoptera: Lymantridae) on Sitka spruce (Picea sitchensis (Bong.) Carr.) in central Scotland. Forestry 59(1): 97-105.

QIU X. \& ARIKAwa K. 2003: The photoreceptor localization confirms the spectral heterogeneity of ommatidia in the male small white butterfly, Pieris rapae crucivora. J. Comp. Physiol. (A) 189: 81-88.

RosenBerg J. \& LANGER H. 2001: Ultrastructural changes of rhabdoms of the eyes of Ocypode species in relation to different regimes of light and dark adaptation. J. Crust. Biol. 21: 345-353.

Robertson K.A. \& Monteiro A. 2005: Female Bicyclus anynana butterflies choose males on the basis of their dorsal UV reflective eyespot pupils. Proc. R. Soc. (B) 272: 1541-1546.

RUTOWSKi R.L. 1977: The use of visual cues in sexual and species discrimination by males of the small sulphur butterfly, Eurema lisa (Lepidoptera: Pieridae). J. Comp. Physiol. 115: 61-74.

Rutowski R.L. 2000: Variation of eye size in butterflies: interand intraspecific patterns. J. Zool. Lond. 252: 187-195.

RUTOWSKI R.L. \& WARRANT E.J. 2002: Visual field structure in the Empress Leilia, Asterocampa leilia (Lepidoptera: Nymphalidae): dimensions and regional variation in acuity. $J$. Comp. Physiol. (A) 188: 1-12.

Sakura M., Takasuga K., Watanabe M. \& Eguchi E. 2003: Diurnal and circadian rhythm in compound eye of cricket
(Gryllus bimaculatus): Changes in structure and photo capture efficiency. Zool. Sci. 20: 833-840.

Schlecht P., Hamdorf K. \& Langer H. 1978: The arrangement of colour receptors in a fused rhabdom of an insect. A Microspectrophotometric study of the moth Deilephila. J. Comp. Physiol. 123: 239-243.

Shimohigashi M. \& Tominaga Y. 1986: The compound eye of Parnara guttata (Insecta: Lepidoptera: Hesperiidae): Fine structure of the ommatidium. Zoomorphol. 106: 131-136.

Stavenga D.G., Kinoshita M. \& Yang E.C. 2001: Retinal regionalization and heterogeneity of butterfly eyes. Naturwissenschaften 88: 477-481.

Sversson M. 1996: Sexual selection in moths: the role of chemical communication. Biol. Rev. 71: 113-135.

TAMmaru T. \& HaukioJa E. 1996: Captial breeders and income breeders among Lepidoptera-consequences to population dynamics. Oikos 77: 561-564.

TAmmaru T., EsPerk T. \& CAstellanos I. 2002: No evidence for costs of being large in females of Orgyia spp. (Lepidoptera: Lymantriidae): larger is always better. Oecologia 133: 430-438.

Tung L.C. \& Lin J.T. 2000: Morphology of the compound eye of hevea tussock moth, Orgyia postica (Lepidoptera: Lymantridae). Chin. J. Entomol. 20: 179-185 [in Chinese, English abstr.].

Viloria A.L., Pyrcz T.W., Wojtusiak J., Ferrer-Paris J.R., Beccaloni G.W., Sattler K. \& Lees D.C. 2003: A brachypterous butterfly? Proc. R. Soc. Lond. (B) (Suppl.) 270: S21-S24.

Warrant E.J. \& McIntyre P.D. 1990: Limitations to resolution in superposition eyes. J. Comp. Physiol. (A) 167: 785-803.

Warrant E.J. \& McIntyre P.D. 1991: Strategies for retinal design in arthropod eyes of low F-number. J. Comp. Physiol. (A) 168: 499-512.

Warrant E., Bartsch K. \& Günther C. 1999: Physiological optics in the hummingbird hawkmoth: A compound eye without ommatidia. J. Exp. Biol. 202: 497-511.

WiLLIAMS D.S. 1982: Ommatidial structure in relation to turnover of photoreceptor membrane in the locust. Cell Tissue Res. 225: 595-617.

Yagi N. \& Koyama N. 1963: The Compound Eye of Lepidoptera: Approach from Organic Evolution. Shinkyo Press, Tokyo, $318 \mathrm{pp}$.

Ziemba K.S. \& Rutowski R.L. 2000: Sexual dimorphism in eye morphology in a butterfly, Astercampa leilia (Lepidoptera: Nymphalidae). Psyche 103: 25-36.

Received September 11, 2006; revised and accepted November 16, 2006 